\title{
The problem of spiritual and moral potential fulfillment in the works of Russian literature in the context of the contemporary educational system
}

\author{
Aleksandr V. Kamenets ${ }^{1 *}$, Natalia I. Anufrieva ${ }^{1}$, Anna I. Shcherbakova ${ }^{2}$, Eugeny A. \\ Anufriev $^{3}$, and Elena $O$. Kuznetsova ${ }^{4}$ \\ ${ }^{1}$ Russian State Social University, Faculty of Arts, Moscow, Russia \\ ${ }^{2}$ Moscow State Institute of Music named after A.G. Schnittke, Moscow, Russia \\ ${ }^{3}$ Moscow State Institute of Music named after A.G. Schnittke, Department of Folk Performing Arts, \\ Moscow, Russia \\ ${ }^{4}$ Herzen State Pedagogical University of Russia, Department of the Institute of Music, Theater and \\ Choreography, Department of Musical and Instrumental Training, Saint Petersburg, Russia
}

\begin{abstract}
The article considers the possibilities of using Russian classical literature in the contemporary learning activity. The authors reveal promising areas and pedagogical strategies for involving the younger generation in the learning of literary classics, as well as propose new conceptual approaches to solving this problem in contemporary society. The article deals with the results of the conducted study on the capabilities of fiction in forming the worldview and value orientations of the younger generation, as well as outlines the further prospects in improving the efficiency of spiritual and moral upbringing of the younger generation based on literary works. The article describes the advantage of value-oriented immersion of pupils in literary and artistic reality, which consists in the possibility of discussing many personal problems of children, adolescents, and young people in an indirect form, using the example of literary plots, characters, situations described in the works, which contributes to the necessary self-revelation of the participants in such discussions. The pedagogical strategy considered in the article is implemented through the creation of a kind of "intertext", which, in contrast to its usual postmodern version of the information space with computer information technologies, is a process of "imposition" of several communicative spaces, namely, pedagogical, "existential experience" of students, literary and artistic reality, and scenery-directing space.
\end{abstract}

Keywords: education, upbringing, development, pedagogy, spirituality, morality, literature.

\footnotetext{
${ }^{*}$ Corresponding author: kamenez.a@,rambler.ru
} 


\section{Introduction}

The study of the problem of underestimating the importance of national literary and artistic achievements in mass education and the upbringing of the younger generation involves an appeal to the achievements of foreign and domestic philosophical, aesthetic, pedagogical, and ethical thought, which contains many program provisions that remain relevant for the modern educational process of artistic and humanitarian orientation. Here one can distinguish foreign thinkers, such as Aristotle, Hegel, Kant, Plato, Schiller [1-5], and others, as well as Russian philosophers and religious thinkers, such as N. Berdyaev, V. Solovyov, and P. Florensky [6-8].

The novelty of the present research was to identify possible and desirable educational strategies for using the spiritual potential of Russian literary works when forming the younger generation at all age stages in the context of various educational disciplines.

The main research hypothesis was the demand for the development of literature and art works in contemporary learning activities as one of the most important resources for improving the efficiency of pedagogical activities of educational institutions of any profile and level, focused on the social, spiritual, and moral development of students' personalities.

The purpose of the study was determined according to this hypothesis. Thus, the research goal was to identify the essential characteristics of domestic works of literature and art that were important for contemporary educational activities and to determine further prospects aimed at improving the functioning of educational institutions and organizations that creatively used these works in spiritual and moral upbringing.

According to this goal, the following tasks were solved:

- studying the content of domestic works of literature and art that were relevant for the spiritual and moral upbringing of the individual;

- considering the initial conceptual and value-worldview grounds for improving arts education aimed at the spiritual and social development of the individual, presented in philosophical and scientific studies;

- analyzing the existing pedagogical practice of studying works of literature and art in mass education, its problems, and achievements in the context of socialization and spiritual development of the younger generation.

\section{Methods}

In the study of domestic works of literature and art that are relevant for the formation of the contemporary educational system, the method of pedagogical simulation of problematic situations in social interaction that arose in the course of socialization and inculturation of the younger generation was used $[9,10]$.

Consideration of the initial conceptual and value-worldview grounds for improving art education aimed at the spiritual and social development of the individual was carried out employing the comparative analysis of the works of Russian philosophers in the field of ethics, and spiritual and moral development of the individual, as well as the priorities established in contemporary educational practice, focused on the modernization of Russian society. In this regard, special attention was paid to the works of V. Zenkovsky, I. Ilyin, V. Solovyov, and P. Florensky [7, 8, 11, 12], who considered various possibilities of expanding the experience of the spiritual transformation of the individual on the paths of a religious worldview. The "zones of solitude" necessary in this context, which is pointed out by Ilyin [12], can be formed through forming artistic and aesthetic requests in the individual perception of works of fiction.

Special attention was paid to Russian classical fiction, which was considered as culturalanthropological and "life-knowledge" cognition. The research implemented conceptual 
approaches to the study of literature based on the "anthropocentric" approach developed in the works of M.M. Bakhtin and D.S. Likhachov [13, 14]. This made it possible to focus the research on the possibilities of studying the most relevant spiritual and psychological problems of the individual using fiction, which remain relevant for the spiritual and moral upbringing of the contemporary younger generation.

\section{Results}

When students studied fiction, the main idea was emphasized on the formation of a personality that was ready for social service and taking care of others. This inner pathos is inherent in most works of Russian classical literature which has great influence on the formation of the Russian national character.

Another common motive in Russian literature is the readiness for empathy, understanding of the problems of others, and compassion. It is this feature of the works of Russian writers that F.M. Dostoevsky had in mind when he claimed that his generation of writers came out of Gogol's "Overcoat".

The discrepancy between "external" and "internal", when manifesting literary characters, provided the necessary educational, spiritual, and moral impact on the readership. In this regard, the technique of "tearing off masks" from many characters, well-known in Russian literature, was expressed as showing different relations between the formal role-playing behavior of literary characters, and their informal, private existence, the sphere of interpersonal relationships, and interactions in personal life.

During 2010-2015, the possibilities of overcoming the postmodern paradigm in contemporary pedagogical practice were identified as leaving no room for students, when studying a foreign piece of writing, to search for stable and well-thought-out constructive ways out of their own problematic life situations by the example of works of literature and art [15].

Accordingly, the next stage in the study of the possibilities of works of literature and art in the formation of the spiritual and moral culture of the younger generation consisted in reformatting and rethinking the literary and artistic material as pedagogically significant in the framework of a new direction of cultural and cognitive activity. It was called the paradigm of social interaction, and developed from 2015 to 2020, assuming the inclusion of a significant "other" in the education and upbringing process [16]. This "subject" is, ultimately, the embodiment of interest, attention, respect, care, and other manifestations towards other people expressed in thoughts, feelings, and actions. This orientation "to the other" is the only real way to overcome the inner loneliness and "existential abandonment" that "Postmodernism" has bestowed on humanity.

The paradigm of interaction in the artistic and pedagogical system is most clearly demonstrated in various interactive pedagogical technologies that promote the development of self-reflection, the ability to combine virtual and physical reality in relationships with social media, and the universe of artistic culture.

The corresponding new accents implemented in the pedagogical organization of the study of literary works are presented in the Table 1 below.

Table 1. New accents implemented in the pedagogical organization of the study of literary works.

\begin{tabular}{|l|l|l|}
\hline $\begin{array}{c}\text { Grounds for studying } \\
\text { works of literature and art }\end{array}$ & \multicolumn{1}{|c|}{$\begin{array}{c}\text { Postmodernism-based } \\
\text { pedagogical paradigm }\end{array}$} & $\begin{array}{c}\text { New pedagogical paradigm } \\
\text { (Post-postmodernism, or } \\
\text { interactionism) }\end{array}$ \\
\hline $\begin{array}{l}\text { Starting position in relations } \\
\text { with the world of literature } \\
\text { and art }\end{array}$ & $\begin{array}{l}\text { Confirming the need for } \\
\text { individualism and "existential } \\
\text { abandonment" in works of } \\
\text { literature and art }\end{array}$ & $\begin{array}{l}\text { Involvement in communication } \\
\text { and interaction with literary } \\
\text { characters and the author of the } \\
\text { literary work enjoying equal rights }\end{array}$ \\
\hline
\end{tabular}




\begin{tabular}{|c|c|c|}
\hline $\begin{array}{l}\text { The purpose of studying } \\
\text { works of literature and art }\end{array}$ & $\begin{array}{l}\text { Testing the existing order } \\
\text { rigidity on the example of } \\
\text { works of art }\end{array}$ & $\begin{array}{l}\text { Search for meanings and } \\
\text { harmonization with the social } \\
\text { environment using works of art }\end{array}$ \\
\hline $\begin{array}{l}\text { Information environment for } \\
\text { studying works of literature } \\
\text { and art }\end{array}$ & $\begin{array}{l}\text { Mosaic information space, } \\
\text { random intertext }\end{array}$ & $\begin{array}{l}\text { Combining pedagogical, } \\
\text { existential, artistic, and social } \\
\text { information spaces }\end{array}$ \\
\hline $\begin{array}{l}\text { Using works of literature } \\
\text { and art to solve own life } \\
\text { problems }\end{array}$ & $\begin{array}{l}\text { Experimentation, trials, and } \\
\text { mistakes based on the study of } \\
\text { literature and art }\end{array}$ & $\begin{array}{l}\text { The attitude to literature and art as } \\
\text { a possibility of reflecting an } \\
\text { interaction with the environment, } \\
\text { constructing relations with it }\end{array}$ \\
\hline $\begin{array}{l}\text { Results of familiarizing with } \\
\text { literature and art }\end{array}$ & $\begin{array}{l}\text { Literature and art as an } \\
\text { arbitrary immersion into } \\
\text { parallel virtual reality } \\
\text { ("escapism") }\end{array}$ & $\begin{array}{l}\text { Building own living environment } \\
\text { and microdynamics of real-life } \\
\text { activity }\end{array}$ \\
\hline $\begin{array}{l}\text { Pedagogical consequences } \\
\text { of studying works of } \\
\text { literature and art }\end{array}$ & $\begin{array}{l}\text { Loss of stable value and } \\
\text { worldview orientations }\end{array}$ & $\begin{array}{lrr}\text { Correlating one's own life } & \text { own } \\
\text { experience with } & \text { universal } \\
\text { humanistic values and guidelines }\end{array}$ \\
\hline
\end{tabular}

\section{Discussion}

The discussed content of works of fiction was "immersed inside" the life experience of the very students, which contributed to its actualization and stimulation of the independent cognitive activity of the participants.

The testing of a new pedagogical strategy based on the immersion of literary works in the context of topical issues for children, adolescents, and youth social medium, logically ended with the subjective understanding of the content of artistic works by teachers as a concretization of socio-cultural norms of social significance. This work was carried out using the example of the fables of I.A. Krylov, which contributed to their inclusion in the contemporary educational system. At the same time, the procedure for comprehending this literary genre was carried out in the context of urgent problems of contemporary society, such as problems of management, law, morality, politics, economics, spiritual life, and personality $[17,18]$.

\section{Conclusion}

Russian pedagogy constantly faces the problem of spiritual and moral disorientation of the younger generation. In this context, the study of works of fiction as a "textbook of life", in which, in one way or another, the achievements of domestic and world spiritual and moral culture are presented, is of particular importance. The main difficulty in assimilating this experience is to correlate it with the life experience of very children, adolescents, and young people.

The solution to the problem of bringing the content of literary works closer to the interests of students lies in the development of creative thinking in children, adolescents, and young people, and the formation of an emotional attitude to artistic and cognitive information as an essential vital experience. The new pedagogical strategy was to consider together with the students literary characters, plots, images, and author's ideas as relating to contemporary society.

\section{References}

1. Aristotle, Etika [Ethics] (Eksmo, Moscow, 2019) 
2. G.W.F. Hegel, Fenomenologiya duha [The phenomenology of spirit] (Vladimir Dal, Saint Petersburg, 2019)

3. I. Kant, Kritika prakticheskogo razuma [Critique of practical reason] (Eksmo, Moscow, 2015)

4. Plato, Gosudarstvo [Republic] (Akademicheskiy Proekt, Moscow, 2015)

5. F. Schiller, Pisma ob esteticheskom vospitanii cheloveka [On the aesthetic education of man in a series of letters] (RIPOL classic, Moscow, 2018)

6. N. Berdyaev, Filosofiya tvorchestva, kultury i iskusstva [Philosophy of creativity, culture and art] (Liga iskusstvo, Moscow, 1994)

7. V.S. Solovyov, Dukhovnyye osnovy zhizni [Spiritual foundations of life] (DirektMedia, Moscow, 2015)

8. P. Florensky, Ikonostas [Iconostasis] (Mifril, Russkaya kniga, Saint Petersburg, 1993)

9. E.V. Koverkina, A.I. Shcherbakova, Sushchnost' $i$ soderzhaniye protsessa sotsializatsii lichnosti v sovremennykh sotsiokul'turnykh usloviyakh [The essence and content of the process of socialization of the individual in modern socio-cultural conditions], in Khudozhestvennoye prostranstvo kul'tury tret'yego tysyacheletiya: problemy nauki i obrazovaniya. Sbornik nauchnykh trudov MGIM im. A. Shnitke RGSU [Artistic space of culture of the third millennium: problems of science and education. Collection of scientific papers of the MSIM named after A.G. Schnittke RSSU], 53-59 (Russian State Social University, Moscow, 2019)

10. N.I. Anufrieva, I.G. Androsova, O.Y. Shvetsova, V.A. Dmitriyev, S.A. Kurbanov, Journal of Advanced Research in Dynamical and Control Systems, 12(SI3), 580-587 (2020)

11. V. V. Zenkovsky, Problemy vospitaniya v svete khristianskoy antropologii [Problems of education in the light of Christian anthropology], Part 1 (YMCA-Press, Paris, 1934)

12. I. Ilyin, Osnovy khristianskoy kultury [The basis of christian culture ] (Eksmo, Moscow, 2011)

13. M.M. Bakhtin, Tvorchestvo Fransua Rable i narodnaja kultura srednevekovja i Renessansa [Rabelais and His World] (Khudozhestvennaya literatura, Moscow, 1990)

14. D.S. Likhachov, A.M. Panchenko, "Smehovoi mir" Drevnei Rusi [Laughing World of Ancient Rus] (Nauka, Leningrad, 1976)

15. E.A. Orlova, Istoriya antropologicheskih ucheniy [History of anthropological studies] (Akademicheskiy Proekt, Moscow, 2010)

16. A.V. Kamenets, Vvedeniye v teoriyu sotsialnogo vzaimodeystviya [Introduction to social interaction theory] (Russian State Social University, Moscow, 2015).

17. A.V. Kamenets, Iskusstvo zhit. Razmyshleniya kulturologa nad basnyami I.A. Krylova [Art of living. Reflections of a culturologist on the fables of I.A. Krylova] (RITM, Moscow, 2020)

18. D. Svyatopolk-Mirsky, Istoriya russkoy literatury s drevneyshikh vremen po 1925 god [History of Russian literature from ancient times to 1925] (Svinyin i synovya, Novosibirsk, 2009) 